\title{
Coagulopathy following venous air embolism: a disastrous consequence
}

\section{-a case report-}

\author{
Srilata Moningi, Dilip Kulkarni, and Suchanda Bhattacharjee \\ Department of Anesthesia, Nizams Institute of Medical Sciences, Hyderabad, India
}

Venous air embolism (VAE) is a life-threatening complication of some surgical procedures. Though occurrence of VAE is frequent during neurosurgical procedures, coagulopathy following VAE has not previously been reported. Coagulation abnormalities are more commonly reported associated with fat or amniotic fluid embolism, but rarely with VAE. We present a case of massive VAE in sitting position leading to fatal coagulopathy even after successful resuscitation following the event. Coagulation abnormalities and bleeding can produce catastrophic consequences in neurosurgical patients. This report emphasizes the possibility of this potentially fatal complication in patients who have sustained a massive VAE. (Korean J Anesthesiol 2013; 65: 349-352)

Key Words: Air embolism, Coagulation abnormalities, Neurosurgical procedures, Sitting position.

Venous air embolism (VAE) is a life-threatening complication of some surgical procedures, especially posterior fossa surgery [1-3]. The cardiac and pulmonary consequences of VAE are well known, however coagulation abnormalities rarely occur with VAE [4]. We present a case of massive VAE leading to fatal coagulopathy even after successful resuscitation following VAE.

\section{Case Report}

An 18 year-old female patient was scheduled for a craniotomy and excision of a mid-brain ependymoma in a seated position. Her clinical, biochemical and coagulation parameters were normal. In the operating theatre, standard monitors (electrocardiograph [ECG], non invasive blood pressure, pulse oximeter) were attached. General anesthesia was induced with fentanyl and thiopentone and intubation was facilitated with vecuronium. Anesthesia was maintained with oxygen, air, isoflurane, fentanyl and atracurium with controlled ventilation using a tidal volume of $500 \mathrm{ml}$ and respiratory rate (RR) of 12 breaths/min to achieve normocarbia. Intra-operative monitoring (using a Datex Ohmeda S5) included heart rate, ECG, oxygen saturation by pulse oximetry, RR, end-tidal carbon dioxide $\left(\mathrm{EtCO}_{2}\right)$, central venous pressure (CVP) (via the basilic vein), invasive blood pressure, airway pressure, volume of intravenous fluids infused,

Received: August 28, 2012. Revised: 1st, October 22, 2012; 2nd, October 31, 2012. Accepted: November 7, 2012.

Corresponding author: Srilata Moningi, M.D., Department of Anesthesia, Nizams Institute of Medical Sciences, Flat No.G-3, Sujatha Sterling Homes, H.No.8-2-403/A, Road No. 4, Banjara Hills, Hyderabad, Andhra Pradesh 500034, India. Tel: 91-040-6456420, Fax: 91-40-23310076, E-mail: srilata_m1973@yahoo.co.in

(c) This is an open-access article distributed under the terms of the Creative Commons Attribution Non-Commercial License (http:// creativecommons.org/licenses/by-nc/3.0/), which permits unrestricted non-commercial use, distribution, and reproduction in any medium, provided the original work is properly cited. 
urine output, nasopharyngeal temperature, arterial blood gas $(\mathrm{ABG})$, blood glucose and blood loss. Transesophageal echocardiography was not monitored as this was not available in our institute. There were no hemodynamic changes during moving the patient to a seated position. Baseline ABG analysis and CVP were normal.

At the time of opening of the dura, there was a sudden decrease in $\mathrm{EtCO}_{2}$ from 36 to $20 \mathrm{mmHg}$ and then, further, to 15 $\mathrm{mmHg}$. Concurrently there was a small tear in the occipital sinus. A VAE was therefore suspected. The $\mathrm{EtCO}_{2}$ changes observed during the VAE, with corresponding arterial blood gas analyses, are depicted in Table 1 . There were no associated changes in hemodynamics or oxygenation. The $\mathrm{EtCO}_{2}$ returned to normal within a few minutes, following measures such as administration of $100 \%$ oxygen and prevention of further air entrainment through packing of the surgical site with salinesoaked gauze. The tear in the occipital sinus was identified and clipped.

Excision of the tumor was uneventful, and intra-operative blood loss during the excision was around $500 \mathrm{ml}$. CVP was maintained at around $11-14 \mathrm{cmH}_{2} \mathrm{O}$. The patient remained hemodynamically stable. During the final stages of dura closure, application of the Valsalva maneuver was requested by the surgeon to check for cerebrospinal fluid leaks and assess the ad- equacy of hemostasis. Immediately after releasing the sustained positive pressure during the Valsalva maneuver, the $\mathrm{EtCO}_{2}$ again suddenly decreased from 30 to $9 \mathrm{mmHg}$, followed by a reduction in blood pressure to $62 / 30 \mathrm{mmHg}$ and ST-T depression by 1 $\mathrm{mmHg}$. Precordial auscultation at the apex of the heart revealed a mill-wheel murmur. The $\mathrm{PaCO}_{2}$ to $\mathrm{EtCO}_{2}$ gradient was 39 mmHg (Table 1). A massive VAE was contemplated and the surgeon was cautioned.

Immediately, 100\% oxygen was administered and the incision site was packed with saline-soaked gauze pieces. The patient was then repositioned in a left lateral recumbent position. About 50$60 \mathrm{ml}$ of air was aspirated from the central venous catheter. She was resuscitated with $1 \mathrm{~L}$ of intravenous voluven ${ }^{\circledR}$ (6\% hydroxyethyl starch $130 / 0.4$ in $0.9 \%$ sodium chloride injection) and an injection of $6 \mathrm{mg}$ mephenteramine. Blood pressure and $\mathrm{EtCO}_{2}$ returned to normal. The mill-wheel murmur disappeared. Soon afterwards, the rest of the surgical procedure was continued in the lateral position.

At the time of wound closure, bleeding was noted from the suture line and the wound was therefore reopened to check for the source of the bleeding. The bleeding from the wound was diffuse, with no identifiable bleeding site. An abnormality in coagulation was suspected. Since blood loss was high and hemostasis could not be obtained surgically, two units of packed

Table 1. Trends in Arterial Blood Gas Analyses and Their Relation to End-tidal $\mathrm{CO}_{2}$ Concentration $\left(\mathrm{EtCO}_{2}\right)$

\begin{tabular}{|c|c|c|c|c|c|c|c|c|}
\hline Time & $\begin{array}{l}\text { Hemoglobin } \\
\quad(\mathrm{gm} / \mathrm{dl})\end{array}$ & $\mathrm{pH}$ & $\begin{array}{c}\mathrm{PaCO}_{2} \\
(\mathrm{mmHg})\end{array}$ & $\begin{array}{c}\mathrm{PaO}_{2} \\
(\mathrm{mmHg})\end{array}$ & $\begin{array}{l}\text { Potassium } \\
(\mathrm{mEq} / \mathrm{dl})\end{array}$ & $\begin{array}{c}\text { Base } \\
\text { excess }\end{array}$ & $\begin{array}{l}\text { Blood sugar } \\
\quad(\mathrm{mg} / \mathrm{dl})\end{array}$ & $\begin{array}{c}\mathrm{EtCO}_{2} \\
(\mathrm{mmHg})\end{array}$ \\
\hline Baseline (after induction) & 11.0 & 7.36 & 33.9 & 146 & 3.5 & -5.9 & 150 & 28 \\
\hline $1 \mathrm{hr}$ after induction ( $1^{\text {st }}$ minor episode of VAE) & 10.3 & 7.24 & 46.6 & 439 & 3.9 & -6.8 & 106 & 15 \\
\hline 20 min after episode & 10.1 & 7.25 & 46.1 & 255 & 3.7 & -6.6 & 119 & 30 \\
\hline At time of dural closure (major episode) & 9.5 & 7.10 & 47.8 & 338 & 3.9 & -9.7 & 123 & 9 \\
\hline 30 min after major episode & 7.2 & 7.20 & 40.1 & 306 & 2.9 & -10.7 & 100 & 28 \\
\hline $1 \mathrm{hr}$ after major episode & 7.3 & 7.20 & 57.3 & 273 & 3.3 & -7.7 & 135 & 32 \\
\hline
\end{tabular}

Table 2. Serial Daily Coagulation Profile with Interventions

\begin{tabular}{|c|c|c|c|}
\hline $\begin{array}{l}\text { Day of surgery/ } \\
\text { presentation }\end{array}$ & Tests for coagulation & Intervention & Parameters after intervention \\
\hline 0 (day of surgery) & Increased surgical site bleeding & 2 PRBCs, 4 FFPs, 4 PRPs & $\begin{array}{c}\mathrm{Hb}-8.4 \mathrm{gm} \% \text {, PLT }-180 \times 10^{9} / \mathrm{L}, \mathrm{PT}-11.8 \mathrm{sec}, \\
\text { aPTT }-20.5 \mathrm{sec} \text {, plasma fibrinogen }-4.0 \mathrm{~g} / \mathrm{dl}\end{array}$ \\
\hline $1^{\text {st }}$ PO day & $\begin{array}{l}\mathrm{Hb}-7.0 \mathrm{gm} \% \text {, PLT }-100 \times 10^{9} / \mathrm{L}, \mathrm{PT}-21.8 \mathrm{sec}, \\
\mathrm{aPTT}-50.5 \mathrm{sec} \text {, plasma fibrinogen }-2.4 \mathrm{~g} / \mathrm{dl}\end{array}$ & 2 PRBCS, 4 FFPs, PRPs & $\begin{array}{l}\mathrm{Hb}-8.0 \mathrm{gm} \% \text {, PLT }-180 \times 10^{9} / \mathrm{L}, \mathrm{PT}-18.1 \mathrm{sec}, \\
\mathrm{aPTT}-20.5 \mathrm{sec} \text {, plasma fibrinogen }-2.0 \mathrm{~g} / \mathrm{dl}\end{array}$ \\
\hline $2^{\text {nd }}$ PO day & $\begin{array}{l}\mathrm{Hb}-8.8 \mathrm{gm} \%, \mathrm{PLT}-100 \times 10^{9} / \mathrm{L}, \mathrm{PT}-22.5 \mathrm{sec}, \\
\mathrm{aPTT}-50.0 \mathrm{sec}\end{array}$ & 2 PRPS, 4 FFPs & $\begin{array}{l}\mathrm{Hb}-8.4 \mathrm{gm} \%, \mathrm{PLT}-160 \times 10^{9} / \mathrm{L}, \mathrm{PT}-14.8 \mathrm{sec}, \\
\mathrm{aPTT}-32.5 \mathrm{sec}\end{array}$ \\
\hline $3^{\text {rd }}$ PO day & $\begin{array}{l}\mathrm{Hb}-7.5 \mathrm{gm} \%, \mathrm{PLT}-60 \times 10^{9} / \mathrm{L}, \mathrm{PT}-24.5 \mathrm{sec} \\
\mathrm{aPTT}-43.0 \mathrm{sec}\end{array}$ & 2 PRBCs, 4 PRPs, 4 FFPs & $\begin{array}{l}\mathrm{Hb}-9.1 \mathrm{gm} \% \text {, PLT }-100 \times 10^{9} / \mathrm{L}, \mathrm{PT}-17.8 \mathrm{sec} \\
\mathrm{aPTT}-30.5 \mathrm{sec} \text {, plasma fibrinogen }-3.2 \mathrm{~g} / \mathrm{dl}\end{array}$ \\
\hline $4^{\text {th }}$ PO day & $\begin{array}{c}\mathrm{Hb}-7.4 \mathrm{gm} \% \text {, PLT }-80 \times 10^{9} / \mathrm{L}, \mathrm{PT}-22.8 \mathrm{sec} \\
\text { aPTT }-60.5 \mathrm{sec}, \text { plasma fibrinogen }-2.1 \mathrm{~g} / \mathrm{dl}\end{array}$ & 2 PRBCs, 4 FFPs, 4 PRPs & $\begin{array}{l}\mathrm{Hb}-8.6 \mathrm{gm} \% \text {, PLT }-180 \times 10^{9} / \mathrm{L}, \mathrm{PT}-18.8 \mathrm{sec}, \\
\mathrm{aPTT}-40.5 \mathrm{sec} \text {, plasma fibrinogen }-1.9 \mathrm{~g} / \mathrm{dl}\end{array}$ \\
\hline $5^{\text {th }} \mathrm{PO}$ day & Diffuse oozing & $\begin{array}{l}\text { Dopamine and } \\
\text { adrenaline support }\end{array}$ & None \\
\hline
\end{tabular}

PO day: post-operative day, Hb: hemoglobin, PT: Prothrombin time, aTTP: activated partial thramboplastin time, PRBCs: packed red blood cells, FFPs: fresh frozen plasma, PRPs: platelet-rich plasma. 
red blood cells (PRBCs), four units of fresh frozen plasma (FFPs) and four units of platelet-rich plasma (PRPs) were administered without waiting for the coagulation profile report. Initially, the blood began to clot and the bleeding stopped. The patient was shifted to the neurosurgical intensive care unit for post-operative ventilation and observation. Later, there was continued oozing from the operative site and from the external ventricular drain (EVD). A post-operative computerized tomography scan of the brain showed a hematoma at the operative site, which was evacuated on the first post-operative (PO) day. Surgical findings showed further oozing from the operative site and surrounding cerebellar surfaces. These were corrected with blood and blood products. The patient's blood parameters and coagulation profile, with interventions made in the following PO days are shown in Table 2. There was continued oozing at the operative site and also from other intravenous and arterial cannulation sites. She deteriorated neurologically, showing clinical features of raised intracranial pressure and an EVD persistently draining blood. On the fourth PO day, inotropic support was initiated, as the patient developed persistent hypotension along with a decreasing Glasgow Coma Scale value and absent pupillary reaction. Finally, on the fifth PO day, she passed away despite resuscitative measures.

\section{Discussion}

Coagulation abnormalities such as disseminated intravascular coagulation (DIC) have been reported in association with amniotic fluid and fat embolisms [5,6]. But coagulopathy complicating a venous air embolism is rare. Fatal VAE with DIC has also been reported with transurethral incision of the bladder [4]. The occurrence of VAE is frequent during neurosurgical procedures. The management protocols for air embolism emphasize the optimization of hemodynamics and gas exchange. Coagulopathy with VAE during neurosurgical procedures has not been reported.

The presence of a rent in the venous sinus with the patient in a sitting position would have resulted in the initial episode of VAE in the above report, though the filling pressures were adequate. The temporal relation between the release of sustained positive pressure and the second episode of air embolism suggests that the ligature clip that was applied to the rent might have slipped off from the venous sinus during the Valsalva maneuver. The large $\mathrm{PaCO}_{2}$ - $\mathrm{EtCO}_{2}$ gradient, mill-wheel murmur and significant fall in blood pressure suggest entrainment of a large amount of air [7].

Coagulopathy following an amniotic fluid embolism is a common finding, and occasionally may be the presenting symptom. The potential of the amniotic fluid to induce coagulation is linked to the presence of a functionally active tissue factor, a factor X-activating substance and the urokinase-like plasminogen activator, t-PA $[6,8,9]$. Coagulation disturbances have also been shown to occur with fat embolism [10]. The basic process involves an exaggerated triggering of physiological coagulation. This leads to DIC and, in severe cases, causes abnormal bleeding.

The patient described above developed abnormal bleeding following a massive air embolism, including diffuse bleeding from a surgical wound and cannulation sites. There was no other triggering factor for coagulopathy in this case. The common causes of intra-operative coagulopathy, such as hypotension, hypothermia and acidosis, were excluded. The patient was hemodynamically stable before the episode of VAE and her hemodynamics were restored immediately after resuscitation. It is possible that the VAE resulted in deranged coagulation with disseminated coagulation and subsequent coagulopathy and thrombocytopenia, as commonly seen in other embolic states such as fat and amniotic fluid embolism. Since the incident occurred during a neurosurgical procedure, where intracranial bleeding would be associated with high mortality and morbidity, FFP and platelets were administered based on clinical judgment without waiting for a laboratory evaluation. This could have reduced the diagnostic ability of the coagulation tests. A definitive diagnosis of DIC could not be established as a D-dimer was not available. A persistent reduction in levels of fibrinogen and platelets, and deranged PT and aPTT, even after transfusion of blood products, suggests the possibility of DIC. Another possible cause for abnormal bleeding could be platelet dysfunction due to contact activation.

It has been suggested that, in air embolism, the interaction of Factor VIII with the prostaglandin system and possibly other blood/tissue factors initiates a coagulation derangement. The effects of air embolism on the pulmonary vasculature can lead to serious inflammatory changes in the pulmonary vessels; these include direct endothelial damage and accumulation of platelets, fibrin, neutrophils, and lipid droplets [11,12]. Another possible explanation is that the microbubbles formed due to turbulent flow in the circulation precipitated platelet aggregation and the release of platelet activator inhibitors [12,13], resulting in platelet dysfunction that contributed to the bleeding diathesis and mortality in this case.

Coagulation abnormalities are under-recognized and underemphasized complications of VAE. In neurosurgical patients, where VAE is frequent, these complications can result in devastating neurological consequences and even mortality.

\section{Acknowledgments}

I would like to thank my department for its immense support and especially Dr. Padmaja for her continuous encouragement. 


\section{References}

1. Domaingue CM. Anaesthesia for neurosurgery in the sitting position: a practical approach. Anaesth Intensive Care 2005; $33: 323-31$.

2. Palmon SC, Moore LE, Lundberg J, Toung T. Venous air embolism: a review. J Clin Anesth 1997; 9: 251-7.

3. Sviri S, Woods WP, van Heerden PV. Air embolism - a case series and review. Crit Care Resusc 2004; 6: 271-6.

4. Tsou MY, Teng YH, Chow LH, Ho CM, Tsai SK. Fatal gas embolism during transurethral incision of the bladder neck under spinal anesthesia. Anesth Analg 2003; 97: 1833-4.

5. Dolak JA. Embolic complications in the parturient. Revista Mexicana de Anestesiologia 2006; 29: S55-7.

6. Collins KA, Davis GJ, Lantz PE. An unusual case of maternal-fetal death due to vaginal insufflation of cocaine. Am J Forensic Med Pathol 1994; 15: 335-9.

7. Albin MS. Air embolism. In: Textbook of Neuroanesthesia with Neurosurgical and Neuroscience Perspectives. Edited by Albin MS: New York, McGraw-Hill. 1997, pp 1009-26.

8. Biron-Andreani C, Morau E, Schved JF, Hedon B, Dechaud H. Amniotic fluid embolism with haemostasis complications: primary fibrinogenolysis or disseminated intravascular coagulation? Pathophysiol Haemost Thromb 2003; 33: 170-1.

9. Lockwood CJ, Bach R, Guha A, Zhou XD, Miller WA, Nemerson Y. Amniotic fluid contains tissue factor, a potent initiator of coagulation. Am J Obstet Gynecol 1991; 165: 1335-41.

10. Keith RG, Mahoney LJ, Garvey MB. Disseminated intravascular coagulation: an important feature of the fat embolism syndrome. Can Med Assoc J 1971; 105: 74-6.

11. Shaikh N, Ummunisa F. Acute management of vascular air embolism. J Emerg Trauma Shock 2009; 2: 180-5.

12. Mirski MA, Lele AV, Fitzsimmons L, Toung TJ. Diagnosis and treatment of vascular air embolism. Anesthesiology 2007; 106: 164-77.

13. Schafer ST, Sandalcioglu IE, Stegen B, Neumann A, Asgari S, Peters J. Venous air embolism during semi-sitting craniotomy evokes thrombocytopenia. Anaesthesia 2011; 66: 25-30. 